\title{
INNOVATION CLUSTERS AS AN ASSOCIATION MODEL OF THE SMALL AND MEDIUM-SIZED ENTERPRISES: THE CONTEXT OF REGIONAL DEVELOPMENT
}

\author{
Ivana Kostadinović ${ }^{1}$ \\ Sunčica Stanković ${ }^{2}$
}

DOI: https://doi.org/10.31410/LIMEN.S.P.2020.47

\begin{abstract}
Numerous empirical studies have long been indicated the importance of business infrastructure for economic and regional development. Ensuring long-term economic growth, as well as the creation and development of small and medium enterprises (SMEs), as key drivers of the development of modern economies, requires a high level of efficiency and flexibility of business infrastructure. In the Western Balkans, the absence of a coherent business infrastructure network is the biggest obstacle to the rapid growth of their economies. For this reason, the activities of the Western Balkan governments in the future should be aimed at developing a network of business infrastructure in order to increase the share of the knowledge and services sector with high added value in the economic structure. This paper aims to point out the role of innovative clusters as a model of associating SMEs in the context of regional development.
\end{abstract}

Keywords: Clusters, SMEs, Innovations, Regional development, Business infrastructure.

\section{INTRODUCTION}

$\mathrm{T}$

The importance of business infrastructure for a country, in terms of enabling economic growth, providing opportunities for the development of small and medium enterprises, influencing the greater inflow of foreign direct investment and the introduction of modern technologies in regional and local communities, is undeniable. Business infrastructure is developed through mapping, construction and equipping of industrial zones, industrial parks, business incubators, clusters, logistics and business centers, as well as tourist infrastructure. Clusters stand out as a particularly important form of business infrastructure. The competitiveness of certain industries, especially mature and traditional ones, based on the experience of EU countries, can be significantly increased by connecting companies into clusters. The EU institutions, which in various ways supported a large number of project initiatives in Serbia, as well as many international agencies and organizations have contributed to their support programs and the development of clusters in the Republic of Serbia.

The trend of connecting small and medium enterprises, encouraged by changes in modern business conditions is becoming increasingly significant. Clustering can provide SMEs with progress and prosperity, in terms of increasing their competitiveness, but also achieving sustainable growth and business. Clusters are formed, primarily, due to the necessity of survival of small and medium enterprises. Through mergers, small and medium-sized enterprises imitate the work of large enterprises, while retaining legal and business independence. In this 
way, clusters become competitors or collaborators of large business systems (Bošković and Jovanović, 2009). Companies grouped into clusters have a comparative advantage, which is based on their specialization, cooperation, greater flexibility and diversification (Gligorijević and Kostadinović, 2012). The focus on innovative clusters is based on the belief that innovation is the key to competitive economic growth, which according to Simmie and Sennett (1999), can be the basis of more competitive cities and regions. Innovation clusters are defined as ,groupings of independent undertakings - innovative start-ups, small, medium and large undertakings as well as research organizations - operating in a particular sector and region and designed to stimulate innovative activity by promoting intensive interactions, sharing of facilities and exchange of knowledge and expertise and by contributing effectively to technology transfer, networking and information dissemination among the undertakings in the cluster" $\left({ }^{3}\right.$, p.10). The difference between innovation clusters and other forms of integration of small and medium enterprises (Burdina, Kaloshina \& Chizhik, 2017; Ablaev, 2018) is that companies that are within the cluster do not go for a complete merger (Lee, Lee \& Oh, 2017; Ablaev, 2018), but they create an interaction mechanism that allows them to maintain the status of a legal entity and at the same time cooperate with other companies that make up the second cluster (Yoon, 2017).

Numerous studies indicate the important role of clusters in the planning and implementation of activities aimed at regional development. This is further evidenced by the policies of the most developed EU member states, which strongly encourage the development of national clusters (Tijanić, 2009). Most of the economic events in the Republic of Serbia take place in the capital Belgrade and its surroundings, and two or three other larger urban areas, but to a much lesser extent. Uneven regional development is a feature of the Republic of Serbia (Kostadinović and Stanković, 2020). The consequence is that most of the national territory remains insufficiently valorized and economically exploited. When considering the economic growth and development of the region, it is necessary to keep in mind the dual territorial (spatial or geographical) and relational basis of the constitution of the region (Župan, 2016). Both of these dimensions play an important role in the concept of regional competitiveness, a very important concept in the light of thinking about the conditions for achieving economic growth and development. According to Stopper (1997), both regional and local competitiveness are defined as the ability of subnational economies to attract and retain firms with stable or growing market shares, while maintaining a stable or growing standard of living of business process participants.

Generally speaking, all entities benefit from being in a cluster, in terms of, for example, easier access to information, knowledge exchange, better cooperation with the public sector and research institutions, participation in research projects (Pasha, 2019; Derlukiewicz et al., 2020). Clusters can also be useful for government policy if the government wants to increase innovation, spread technology and knowledge, or in a situation where it wants to increase competitive advantage and even conquer a new market (Ozkanli and Akdeve, 2006). On the other hand, if there is an economic downturn in a particular industry, with excessive concentration and scale of cluster activity, there is a risk that the region will be too dependent on one industry, which may lead to an imbalance in the structure of the economy. Then, regardless of the fact that the cluster contributes to the development of the region, the collapse of the market in which it operates can lead to a regional crisis (Derlukiewicz et al., 2020). 
The results of various studies indicate that the strength of local clusters strongly influences the performance of regional economies. Spencer et al. (2010), based on an analysis of data on Canadian urban regions, as well as Delgado et al. (2014), in the context of American regions, indicate that industries, which are located in an urban region with a critical mass of related industries, tend to generate not only higher revenues, but also employment growth rates. Delgado et al. (2014) also pointed out that regionally leading clusters contribute to the growth of patents of other clusters in the region. On the other hand, Feser et al. (2008), found no evidence of the impact of technology-based clusters in the U.S. Appalachian region on employment growth. The findings of a study conducted by McDonald et al. (2007) suggest that, although established clusters in the UK are associated with employment growth, clusters with deep cooperation networks are not.

\section{RESEARCH METHODOLOGY}

The subject of this study is innovative clusters, as a model of association of small and medium enterprises in the context of regional development. The study aims to explore the relationship between the goals of small and medium enterprises, which operate through technological branches, which are accepted as innovative clusters, innovation perception and regional development. Following the aim of the research, the following hypotheses were set:

Hypothesis One: Desire of clustered firms for making strategic cooperation has a direct positive effect on innovation.

Hypothesis Two: Desire of clustered firms for infrastructure and standards has a direct positive effect on innovation.

Hypothesis Three: Desire of clustered firms for information sharing has a direct positive effect on innovation.

Hypothesis Four: Desire of clustered firms for lobbying has a direct positive effect on innovation.

Hypothesis Five: Innovation has a direct positive effect on regional development.

In order to achieve the goal, a survey was conducted which included 350 respondents, employed in 144 companies in the Republic of Serbia, of which 65\% are small companies, while $35 \%$ are medium-sized companies. The largest percentage of companies employing respondents belong to the automotive cluster of Serbia (36\%), the ICT cluster of central Serbia (28.2\%), the ICT cluster of Vojvodina (19.3\%), the Vojvodina Metal Cluster (16.5\%) and the FACTS cluster. The sample included $54.6 \%$ of male respondents and $45.4 \%$ of female respondents. Of the total number of surveyed subjects, $39.6 \%$ of respondents have a university degree, $19.4 \%$ have a college degree, and $41 \%$ of respondents have a high school education. Among the respondents, most respondents are 35-45 years old (37\%), over 45 years old are $34 \%$ of respondents, while the lowest percentage of respondents in the sample under the age of 35 is $29 \%$. The largest number of employees has been working in the current company for less than 5 years (46\%), 38\% of respondents have been working in the same company for 5-10 years, while $16 \%$ of respondents have been working for more than 10 years.

A questionnaire was used as a data collection tool, which contained open-ended and closedended questions. The questionnaire is designed in seven parts. The questions from the first part referred to the socio-demographic characteristics of the respondents (gender, age, education, work experience). The instrument for measuring regional development, in the second part of the questionnaire, was developed after reviewing the literature relevant to regional development (Stoper, 1997; McDonald et al., 2007; Spencer et al., 2010; Delgado et al., 2014; 
Evgeny et al., 2016; Župan, 2016; Derlukiewicz et al., 2020). The questionnaire was reviewed by three professors, experts in the research area, in order to more precisely formulate the items and the survey structure of the questionnaire. After their answer, two attitudes were corrected, and then the final form of the regional development scale was created - RD, which contains 5 items. The scale Strategic collaboration - SC (4 items), in the third part of the questionnaire, was developed based on Vučić (2010), the scale Information Sharing - IS (3 items), in the fourth part of the questionnaire, was developed based on Ismalin (2011). Scales Innovation - I (4 items), in the fifth part of the questionnaire, Lobbying - L (4 items), in the sixth part of the questionnaire and Infrastructure and standards - IaS (3 items), in the seventh part of the questionnaire, were taken from Anić et al. (2019). Respondents expressed their views on a 5point Likert scale (1 - strongly disagree; 5 - absolutely agree). The questionnaire, in electronic form, was distributed via e-mail. Each questionnaire contained a cover letter, informing the respondents about the needs of the research, the identity of the researcher and the anonymity of the survey. The research, including the pilot test, was conducted in the period February May 2020. The conceptual model of the research is shown in Figure 1.

Figure 1. The conceptual model

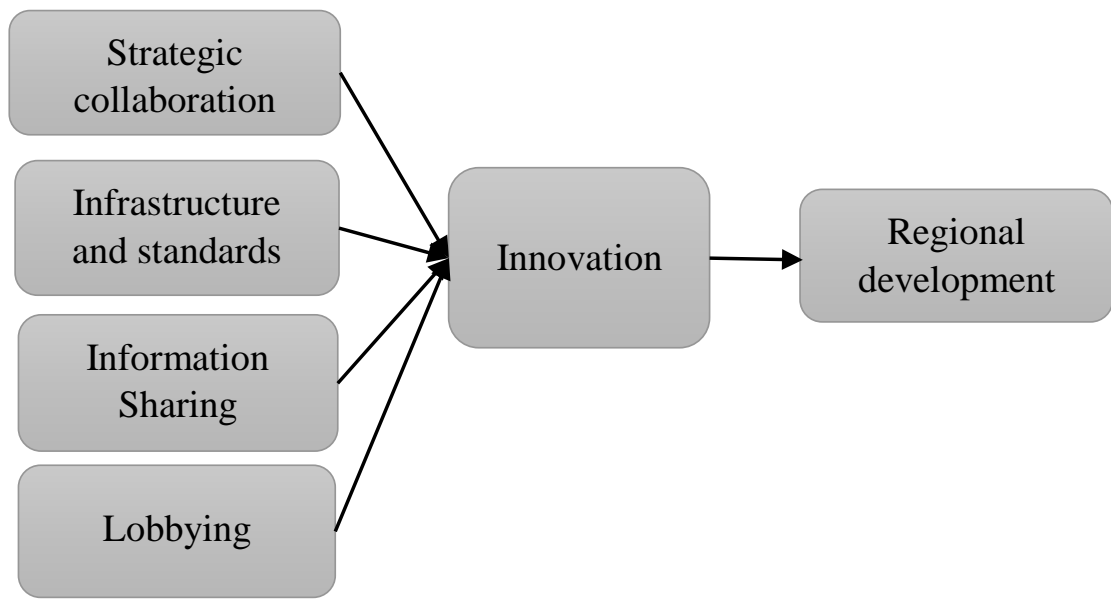

Source: Authors

In the first step, the reliability and validity of the measurement model were tested, followed by the significance of the structural path between the latent variables of the proposed model, based on the two-step approach in estimating the structural equation model proposed by Chin (1998). The measurement model was evaluated based on reliability, convergent validity and discriminant validity. Reliability was assessed based on Cronbach's alpha coefficient and composite reliability. Convergent validity was assessed based on mean isolated variance (AVE), while discriminant validity was assessed based on Fornell-Larker criteria (Fornell and Larcker, 1981). The demographic structure of the respondents was presented using frequency analysis and descriptive statistics. Data were analyzed using statistical software IBM SPSS 21 and AMOS graphics.

\section{RESEARCH RESULTS}

The exploratory factor analysis indicated six factors whose value of the inherent characteristic root is greater than 1. Reliability, as one of the first indicators of the quality of the measuring instrument, was measured by the Cronbach's alpha coefficient. The value of Cronbach's alpha is over 0.7 for each of the six constructs, indicating good internal consistency of the scale. Internal consistency is a necessary, but not a sufficient condition for the validity of the scale, 
so that, in the next step, the psychometric validity of the scale was assessed by applying confirmatory factor analysis. Kaiser-Meyer-Olkin (KMO) is 0.854 , while the value of Bartlett's Test of Sphericity is $1478.185(\mathrm{df}=253 ; \mathrm{p}<0.00)$. The results of confirmatory factor analysis confirmed six factors, and the total variance explained by these six factors was $73.42 \%$.

Table 1. Psychometric properties of measurement model

\begin{tabular}{|c|c|c|c|}
\hline \multirow{2}{*}{ Items } & Constructs & \multirow{2}{*}{ Loadings } & \multirow{2}{*}{$\begin{array}{l}\text { Cronbach's } \\
\text { alpha }\end{array}$} \\
\hline & Regional Development & & \\
\hline V1 & Our cluster has increased earnings in the region & .855 & \multirow{5}{*}{.924} \\
\hline $\mathbf{V 2}$ & $\begin{array}{l}\text { Our cluster has increased the development and } \\
\text { patents growth of other clusters in region }\end{array}$ & .842 & \\
\hline $\mathbf{V 3}$ & $\begin{array}{l}\text { Our cluster has contributed to increasing employment } \\
\text { in the region }\end{array}$ & .843 & \\
\hline V4 & $\begin{array}{l}\text { Our cluster has increased the living standards of the } \\
\text { region's population }\end{array}$ & .824 & \\
\hline \multirow[t]{2}{*}{ V5 } & $\begin{array}{l}\text { Our cluster has contributed to increasing the level of } \\
\text { economic development of the region }\end{array}$ & .840 & \\
\hline & Strategic collaboration & & \multirow{5}{*}{.864} \\
\hline V6 & Our cluster had an EU financed project & .801 & \\
\hline $\mathbf{V 7}$ & $\begin{array}{l}\text { There is a project that our company had worked on } \\
\text { with other companies within the cluster }\end{array}$ & .774 & \\
\hline $\mathbf{V 8}$ & $\begin{array}{l}\text { Our enterprise cooperated with the other enterprises } \\
\text { from the same cluster }\end{array}$ & .739 & \\
\hline \multirow[t]{2}{*}{ V9 } & $\begin{array}{l}\text { Our enterprise cooperated with the other enterprises } \\
\text { from the other cluster }\end{array}$ & .796 & \\
\hline & Innovation & & \multirow{5}{*}{.881} \\
\hline V10 & Facilitate higher innovativeness & .734 & \\
\hline V11 & Diffuse technology within the cluster/sector & .722 & \\
\hline V12 & Attract new firms and talent to sector/industry & .738 & \\
\hline \multirow[t]{2}{*}{ V13 } & Enhance production processes & .830 & \\
\hline & Infrastructure and Standards & & \multirow{4}{*}{.726} \\
\hline V14 & Conduct private infrastructure projects & .824 & \\
\hline V15 & Establish technical standards & .823 & \\
\hline \multirow[t]{2}{*}{ V16 } & Co-ordinate purchasing & .671 & \\
\hline & Lobbying & & \multirow{5}{*}{.755} \\
\hline V17 & Lobby government for infrastructure & .652 & \\
\hline V18 & Improve regulatory policy & .689 & \\
\hline V19 & Lobby for subsidies & .766 & \\
\hline \multirow[t]{2}{*}{ V20 } & Improve FDI incentives & .777 & \\
\hline & Information Sharing & & \multirow{4}{*}{.904} \\
\hline V21 & Sharing of information on technology & .868 & \\
\hline V22 & Sharing of information on products & .807 & \\
\hline V23 & Sharing of information on markets & .889 & \\
\hline
\end{tabular}

Source: Own calculation

To estimate the fitting of the model, the $\chi^{2}$ value was first calculated. The obtained value of the $\chi^{2}$ test is not statistically significant $(\chi 2(218)=248.299 ; p>0.001)$, which indicates a good fit for the model. The normalized value of $\chi 2$ test, which in this case is $\chi^{2} / \mathrm{df}=1.139$, 
indicates a good specification of the model. The obtained values of CFI, SRMR, RMSEA, GFI, IFI and TLI indices, indicate a good fit of the model.

Table 2. Structural model fit indices

\begin{tabular}{|c|c|r|r|r|r|r|c|}
\hline \multirow{2}{*}{$\begin{array}{c}\text { Obtained } \\
\text { values }\end{array}$} & \multicolumn{1}{|c|}{$\boldsymbol{\chi 2} / \mathbf{d f}$} & \multicolumn{1}{c|}{ CFI } & \multicolumn{1}{|c|}{ SRMR } & RMSEA & \multicolumn{1}{c|}{ GFI } & \multicolumn{1}{c|}{ IFI } & TLI \\
\cline { 2 - 8 } & 1.139 & 0.981 & 0.08 & 0.036 & 0.851 & 0.978 & 0.974 \\
\hline
\end{tabular}

Source: Own calculation

Considering the satisfactory values of the fitting index, the validity of the concept was assessed, which implies the degree to which the set of statements represents the concept that is the subject of measurement, and is assessed based on convergent and discriminant validity (Hair et al., 2010). The fulfillment of the conditions of convergent validity is indicated by statistically significant factor loads greater than 0.50 . The fulfillment of the conditions of convergent validity is also indicated by the values of the composite reliability coefficient (CR), which by factors exceed the lower acceptance threshold of 0.70 . For the discriminant validity test, the square root of AVE was calculated. The square roots of the AVEs of all variables were greater than the correlations between the variables, thus confirming the discriminant validity. The results are shown in Table 3.

Table 3. Descriptive statistics, correlation and reliability analysis

\begin{tabular}{|c|c|c|c|c|c|c|c|c|c|c|}
\hline Constructs & M & SD & CR & RD & I & SC & IaS & IS & $\mathbf{L}$ & AVE \\
\hline RD & 4.21 & .60 & .922 & $.839^{*}$ & & & & & & .704 \\
\hline I & 4.23 & .60 & .843 & $.334^{*}$ & $.757^{*}$ & & & & & .573 \\
\hline SC & 4.07 & .45 & .813 & $.205^{*}$ & $.550^{*}$ & $.723^{*}$ & & & & .523 \\
\hline IaS & 3.94 & .47 & .818 & $.110^{*}$ & $.369^{*}$ & $.068^{*}$ & $.776^{*}$ & & & .602 \\
\hline IS & 3.93 & ,47 & .891 & $.373^{*}$ & $.535^{*}$ & $.455^{*}$ & $.138^{*}$ & $.856^{* *}$ & & .732 \\
\hline $\mathbf{L}$ & 4.16 & .56 & .860 & $.561^{*}$ & $.543^{*}$ & $.383^{*}$ & $.047^{*}$ & $.338^{*}$ & $.778^{* * *}$ & .605 \\
\hline
\end{tabular}

Notes: CR, composite reliability; ${ }^{*} \mathrm{p}<0.01 ;{ }^{* *}$ the square root of AVE.

Source: Own calculation

The research results, indicate a significant direct and positive effect on the impact of strategic collaboration on innovation $(\beta=0.305, \mathrm{p}=0.04)$, infrastructure and standards have a direct positive effect on innovation $(\beta=0.306, p=0.001)$, information sharing has direct positive effect on innovation perception $(\beta=0.247, p=0.010)$, and lobbying has a direct positive effect on innovation $(\beta=0.305, \mathrm{p}=0.0001)$. Also, the results indicate a positive direct effect of innovation on regional development $(\gamma=0.547, \mathrm{p}=0.0001)$, thus confirming the hypothesis H5. The table 4 shows the results of hypothesis testing.

Table 4. Hypotheses testing

\begin{tabular}{|c|c|c|c|c|c|c|c|}
\hline Hypothesis & Path & $\begin{array}{l}\text { Standardized } \\
\text { estimate }\end{array}$ & SE & CR & p & $\begin{array}{c}\text { Det. coeff. } \\
\left(\mathbf{R}^{2}\right)\end{array}$ & Result \\
\hline H1 & $\mathrm{SC} \rightarrow \mathrm{I}$ & .305 & .140 & 2.844 & .004 & \multirow{5}{*}{$\begin{array}{l}\mathrm{R}^{2} \mathrm{I}=.234 \\
\mathrm{R}^{2} \mathrm{RD}=.234\end{array}$} & Supp \\
\hline H2 & $\mathrm{IaS} \rightarrow \mathrm{I}$ & .306 & .139 & 3.193 & .001 & & Supported \\
\hline H3 & $\mathrm{IS} \rightarrow \mathrm{I}$ & .247 & .101 & 2.591 & .010 & & Supported \\
\hline H4 & $\mathrm{L} \rightarrow \mathrm{I}$ & .350 & .105 & 3.692 & .0001 & & Supported \\
\hline H5 & $\begin{array}{l}\mathrm{I} \rightarrow \\
\mathrm{RD}\end{array}$ & .382 & .103 & 3.710 & .0001 & & Supported \\
\hline
\end{tabular}

Source: Own calculation 


\section{CONCLUSION}

Enterprises have different expectations, goals and reasons when deciding to join a cluster. Anić et al. (2019), according to the goals of joining the cluster, listed three groups of members: lobbying oriented, networking oriented, and innovation-oriented. Y1ldiz and Zafer (2015) listed as desired goals of cluster members: qualified personnel employment, rivals' observation, strategic collaboration, and information sharing. The result of cluster formation should be the satisfaction of the needs and interests of members within the cluster (Mirković and Lukić, 2013). The study aimed to examine the relationship between the desired goals of the company, which joined the clusters, innovation and regional development.

The findings of the study suggest a significant effect of strategic collaboration on innovation. The obtained results are in accordance with the results of the study by Lopes et al. (2019), who examined how collaboration, in a competitive environment, can affect innovation and pointed out the importance of cooperation in the innovation process. Also, according to Un and Asakawa (2015), R\&D collaboration with suppliers and universities has a positive impact on the innovation process. Collaboration enables companies to access external knowledge, which they can use to obtain innovative products (Un \& Asakawa, 2015).

The findings of the study indicate a positive effect of infrastructure and standards on innovation. The results are in line with Mangiarotti and Riillo (2014), who examined the relationship between standardization and innovation and determined the positive impact of ISO 9000 certification on the likelihood of innovation, in a situation where, in the definition of an innovative company, organizational and marketing innovations are included. The authors point out that certification increases the propensity for innovation in production when the focus is on technological innovation. Feldman and Florida (1994) confirmed the hypothesis that innovation is a function of the technical infrastructure of a particular area. Frenz and Lambert (2012) point out that infrastructure is a key resource for the efficient functioning of innovation, with standards deeply embedded in the ways and styles of innovation practice in the industry.

The findings of the study point to the positive effect of information sharing on innovation. Y1ldız and Zafer (2015), also, found a positive relationship between these two constructs. According to Karanasios (2018), tools that support the exchange of information and cooperation offer the possibility of overcoming long-term challenges in the work between companies.

The findings of the study point to the positive effect of lobbying on innovation. The results of a study conducted by Ozer et al. (2013), show that a larger network size will be even more effective in influencing company innovation, when a company invests in lobbying activities, i.e. that the extent to which networks enable the flow of information is a function of company investment in corporate lobbying.

The findings of the study indicate a positive direct impact of innovation on regional development. However, there is little empirical evidence on the connection between these two constructions, with which comparable results have been obtained. For example, Delgado et al. (2014), based on the results of their study, suggest the complementarity of the relationship between employment and innovation in regional clusters. Besides, the authors state that the strength of related clusters in the region and neighboring regions increases the regional growth of industry, with new industries appearing where there is a strong cluster. Njøs and Jakobsen 
(2016) point out that cluster projects should be operationalized as sources of regional innovation platforms where both the market and technology serve as drivers of innovation.

The main limitation of the conducted study is related to the sample size, due to which generalization is almost impossible. The results indicate the need to increase empirical research, in the context of the relationship between clusters and regional development, which is a key implication of this research. In this regard, further research can be focused on finding cluster policies, which will, above all, support the development of clusters, which significantly contribute not only to regional but, also, to sustainable development.

\section{REFERENCES}

Ablaev, I. (2018). Innovation Clusters and Regional Development. Academy of Strategic Management Journal, Vol: 17 Issue: 3. Available at: https://www.abacademies.org/articles/innovation-clusters-and-regional-development7259.html (11.01.2021.).

Anić, I.D., Corrocher, N., Morrison, A., \& Aralica, Z. (2019). The development of competitiveness clusters in Croatia: A survey-based analysis. European Planning Studies, 27(11), 2227-2247. https://doi.org/10.1080/09654313.2019.1610726

Bošković, G., \& Jovanović, A., (2009), Uticaj klastera na konkurentnost i regionalni razvoj industrije. Ekonomske teme, 47 (1), 107-119.

Burdina, A.A., Kaloshina, M.N. \& Chizhik, A.S. (2017). Comprehensive method of analyzing the investment potential of industrial enterprises. Academy of Strategic Management Journal, 16 (2). Available at: https://www.abacademies.org/articles/comprehensivemethod-of-analyzing-the-investment-potential-of-industrial-enterprises-6860.html (12.01.2021.)

Chin, W. W. (1998). The partial least squares approach for structural equation modeling. In G. A. Marcoulides (Ed.), Methodology for business and management. Modern methods for business research (pp. 295-336). Lawrence Erlbaum Associates Publishers.

Community Framework for State Aid for Research and Development and innovation (2006/C 323/01). (2006). Official Journal of the European Union, 1-26. Available at: http://eurlex.europa.eu/LexUriServ/LexUriServ.do?uri=OJ:C:2006:323:0001:0026:EN:PDF (accessed: 11.10.2021.).

Delgado, M., Porter, M. E., \& Stern, S. (2014). Clusters, convergence and economic performance. Research Policy, 43(10), 1785-1799. https://doi.org/10.1016/j.respol.2014.05.007

Derlukiewicz, N., Mempel-Śnieżyk, A., Mankowska, D., Dyjakon, A., Minta, S., \& Pilawka, T. (2020). How do Clusters Foster Sustainable Development? An Analysis of EU Policies. Sustainability, 12(4), 1297-1131. https://doi.org/10.3390/su12041297

Evgeny, V.F., Mashevskaya, O.V., Ermolina, L.V. (2016). Innovational Mechanism of Implementation of Cluster Initiatives in Business. European Research Studies, XIX (1), 179-188

Feldman, M.P., \& Florida, R. (1994). The geographic sources of innovation: Technological Infrastructure product innovation in the United States. Annals of the Association of American Geographers, 84(2), 210-229. https://doi.org/10.1111/j.14678306.1994.tb01735.x

Feser, E., Renski, H., \& Goldstein, H. (2008). Clusters and economic development outcomes: An analysis of the link between clustering and industry growth. Economic Development Quarterly, 22(4), 324-344. https://doi.org/10.1177\%2F0891242408325419 
Fornell, C., \& Larcker, D.F. (1981). Evaluating structural equation models with unobservable variables and measurement error. Journal of Marketing Research, 18(1), pp. 39-50. https://doi.org/10.2307/3151312

Frenz, M., \& Lambert, R. (2012). Innovation Dynamics and the Role of Infrastructure. BIS Occasional Paper No. 3. London: Department for Business, Innovation and Skills.

Gligorijević, Ž., \& Kostadinović, I., (2012). Industrijski klasteri: važna poluga mehanizma za unapređenje konkurentnosti industrije. (Industrial clusters: an important lever of the mechanism for improving the competitiveness of industry). Nauka+praksa, 15, GAF, 513.

Hair, J. F. Jr., Black W. C., Babin, B. J., and Anderson, R. E. (2010). Multivariate Data Analysis: A Global Perspective. 7th ed. Pearson Prentice Hall.

Ismalina, P. (2011). An Integrated Analysis of Socioeconomic Structures and Actors in Indonesian Industrial Clusters. (Doctoral dissertation). Groningen: University of Groningen.

Karanasios, S. (2018). Information sharing and technological innovation. In book: Community services of the future: An evidence review (pp.47-52). Publisher: Future Social Services Institute.

Ketels, C.; Lindqvist, G.; Solvell, O. (2009). Strengthening clusters and competitiveness in Europe. The Role of Cluster Organisations. Stockholm: The Cluster Observatory, Stockholm School of Economics.

Kostadinović, I., \& Stanković, S. (2020). The analysis of the regional disproportions in the labor market in the Republic of Serbia. Ekonomika, 66(1), 25-35. https://doi.org/10.5937/ekonomika2001025K

Lee, S.J., Lee, E.H., \& Oh, D.S. (2017). Establishing the innovation platform for the sustainable regional development: Tech-valley project in Sejong city, Korea. World Technopolis Review, 6(1), 75-86.

Lopes, A.P., Ferrarese, A., \& de Carvalho, M.M. (2019). Collaboration, competition and innovation: A consortium of tribology in the automotive sector. Produção, 29(1), 1-14. https://doi.org/10.1590/0103-6513.20180106

Mangiarotti, G., \& Riillo, A.F.C. (2014). Standards and innovation in manufacturing and services: the case of ISO 9000. International Journal of Quality \& Reliability Management, 31(4), 435-454. https://doi.org/10.1108/IJQRM-06-2012-0077

McDonald, F., Huang, Q., Tsagdis, D., \& Tuselmann, H. J. (2007). Is there evidence to support Porter-type cluster policies. Regional Studies, 41(1), 39-49. https://doi.org/10.1080/00343400601136284

Mirković, V., \& Lukić, J. (2013). Klasterizacija malih i srednjih preduzeća kao determinanta konkurentnosti i šansa za oporavak srpske privrede. (Clustering of small and medium enterprises as a determinant of competitiveness and a chance for recovery of the Serbian economy). Conference: Konkurentnost preduzeća u Srbiji (Competitiveness of enterprises in Serbia). Niš: Faculty of Economics.

Njøs, R., \& Jakobsen, S.-E. (2016). Cluster policy and regional development: scale, scope and renewal, Regional Studies. Regional Science, 3(1), 146-169. https://doi.org/10.1080/21681376.2015.1138094

Ozer, M., Demirkan, I., \& Gokalp, O.N. (2013). Collaboration networks and innovation: does corporate lobbying matter?. Journal of Strategy and Management, 6(3), 286-308. https://doi.org/10.1108/JSMA-01-2013-0009

Ozkanli, O., \& Akdeve, E. (2006). Cluster and innovation as regional development. Presented in the II. International Strategic Management Conference, 07-09 June 2006, Istanbul. 
Pasha, A. (2019). Role of entrepreneurial universities, research centers and economic zones in driving entrepreneurship and innovation in cluster ecosystems. In book: Proceedings of the II International Triple Helix Summit (pp.59-75). DOI: 10.1007/978-3-030-23898-8_6

Simmie, J., and Sennett, J. (1999). Innovative clusters: global or local linkages?. National Institute Economic Review, 170(1), 87-98. https://doi.org/10.1177/002795019917000112

Storper, M. (1997). The Regional World: Territorial Development in a Global Economy. New York: Guilford.

Spencer, G. M., Vinodrai, T., Gertler, M., S., \& Wolfe, D. A. (2010). Do Clusters Make a Difference? Defining and Assessing their Economic Performance. Regional Studies, 44(6), 697-715. https://doi.org/10.1080/00343400903107736

Tijanić, L. (2009). Politika Europske unije u formiranju klastera. Ekonomska istraživanja, 22 (1), 149-167.

Un, C. A., \& Asakawa, K. (2015). Types of R\&D collaborations and process innovation: the benefit of collaborating upstream in the knowledge chain. Journal of Product Innovation Management, 32(1), 138-153. https://doi.org/10.1111/jpim.12229

Vučić, I. (2010). Cooperation and Cluster Strategies Within and Between TechnologyIntensive Organizations: How to Enhance Linkages among Firms in TechnoParks. Working Paper Series 10/02. Science and Technology Policies Research Center Tekpol.

Y1ldız, T., \& Aykanat, Z. (2015). Clustering and Innovation Concepts and Innovative Clusters: An Application on Technoparks in Turkey. Procedia - Social and Behavioral Sciences, 195, 1196-1205. https://doi.org/10.1016/j.sbspro.2015.06.173

Yoon, D. (2017). The regional-innovation cluster policy for R\&D efficiency and the creative economy: With focus on Daedeok Innopolis. Journal of Science and Technology Policy Management, 8(2), 206-226. https://doi.org/10.1108/JSTPM-09-2016-0025

Župan, Ž. (2016). An analysis of the starting point and a framework draft model for a regional cluster in Lika-Senj county. Zbornik radova Međimurskog veleučilišta u Čakovcu (1847702X), 7(1), 139-156. 